E.S $S_{\text {cripta }} \mathbf{R}_{\text {omanica }}$

vol. 7 (2019): 15-28

\title{
Los rituales de la libertad en la poesía de Rosario Castellanos: de las redes perversas del poder a la autoafirmación
}

\author{
The rituals of freedom in the poetry of Rosario Castellanos: \\ from perverse networks of power to self-affirmation
}

\author{
Lilia Leticia García-Peña \\ Universidad de Colima, México
}

\begin{abstract}
Resumen: Este trabajo analiza la representación simbólica de la dinámica del poder en la poesía completa de Rosario Castellanos, una de las escritoras mexicanas contemporáneas más importantes. Se estudia cómo Rosario Castellanos vincula los efectos de las redes de poder con una dimensión del mal metafísico y se aborda el proceso ritual liberador que la escritora construye en su vida y en su obra para aproximarse a la autoafirmación.
\end{abstract}

Palabras clave: Rosario Castellanos, poder, mal metafísico, ritual, liberación.

\begin{abstract}
In this work we analyze the symbolic representation of the dynamics of power in the complete poetry of Rosario Castellanos, one of the most important contemporary Mexican writers. It is studied how Rosario Castellanos links the effects of power networks with a dimension of metaphysical evil and deals with the liberating ritual process that the writer constructs in her life and in her work in order to approach self-affirmation.
\end{abstract}

Keywords: Rosario Castellanos, power, metaphysical evil, ritual, release.

\section{Introducción}

Rosario Castellanos (1925-1974) es una de las escritoras mexicanas contemporáneas más importantes, la diversidad y vigencia de su obra la convierten en referencia fundamental de la literatura mexicana. Se distingue tanto por la excelencia de su estilo poético como también por su indiscutible compromiso social con aquellos sujetos excluidos y marginados de algún modo. En ese sentido, en su poesía no solo es posible observar la representación simbólica de la dinámica del poder sino más allá, una de las aristas más agudas de este fenómeno, aquello que Michel Foucault reveló como las redes perversas del poder: esa cualidad de ubicuidad del poder que implica la complicidad de todos incluso del mismo sometido para cumplirse.

En este trabajo se analiza la representación simbólica del poder y sus rituales de liberación en la poesía completa de Rosario Castellanos desde la mitocrítica de Gilbert Durand. El análisis se complementa con los conceptos de Michel Foucault en torno al problema del poder y del filósofo Paul Ricœur por lo que se refiere a la 
vinculación entre el problema del poder y el problema del mal metafísico. La argumentación se desarrolla en tres apartados: las redes perversas del poder en la poesía de Rosario Castellanos; el problema del poder y el mal metafísico en la poesía de dicha autora; y rituales de liberación: hacia la autoafirmación.

Octavio Paz (2003) sostiene que "todo libro de poemas es, en el fondo, un diario" (p. 671), en ese sentido puede afirmarse que Castellanos abordó en su proyecto poético con valentía el problema del poder desde su propia experiencia. Lo más importante es que captura, tanto ética como estéticamente, cómo todos los sujetos se suman a estas mallas perversas del poder, volviéndose cómplices incluso del propio sometimiento. La autora plantea en su poesía la vinculación del problema del poder con el problema del mal metafísico en la condición humana. La trascendencia de su obra poética estriba en convertirse en una lucha que se vuelve paradigmática, no solo para asuntos de género y perspectivas femeninas sino para cualquier individuo que asume esta realidad. Rosario Castellanos busca y encuentra, en medio del desastre y la aniquilación que infringe el poder, rituales de liberación y autoafirmación que sellan su vida y su obra.

\section{Las redes perversas del poder en la poesía de Rosario Castellanos}

Castellanos es testigo del racismo y la discriminación social y cultural ya desde su infancia transcurrida en Chiapas, del mismo modo que por patrones familiares, vive una perspectiva también sesgada de las relaciones de género en su entorno. Estos eventos la convierten en una persona especialmente sensible a los contextos del poder lo que le da forma en gran medida a su proyecto estético tanto en cuentos y novelas como en su poesía. En el poema «Ajedrez» escribe:

Henos aquí hace un siglo, sentados, meditando

encarnizadamente

cómo dar el zarpazo último que se aniquile

de modo inapelable y, para siempre, al otro (Castellanos, 2012: 2911).

Su discurso poético reitera una y otra vez el tema del mandato y la obediencia:

Y para obedecer mandatos cuya incomprensibilidad me sobrepasa (101).

Ella no entiende nada. Y obedece (114).

Obedecí, señores, las consignas (227).

Pero, siempre también, cedo. Por obediencia (330).

Sin embargo, del tratamiento del tema del poder en su vida y su obra lo que más deslumbra es que supo ver un matiz tan finísimo y sutil como perverso que se gesta en el seno de los aparatos de poder en nuestras sociedades: el hecho de que todos los individuos, sin discusión y sin duda, participan en sus redes, incluso el mismo sujeto sojuzgado. Puede advertirse que desde los años sesenta señala aspectos que su contemporáneo francés, el gran teórico del poder Michel Foucault (1926-1984), tratará en profundidad años después. En 1962, escribe: "De allí no se sigue que las cosas cambien para mejorar ni que la inocencia corresponda a la víctima y la

\footnotetext{
1 La gran mayoría de las citas de la obra de la autora se refieren a la edición R. Castellanos (2012): Poesía no eres tú. México: FCE. Por este motivo a partir de ahora, las menciones referentes a esta edición se señalarán solamente con el número de página, mientras que las que pertenezcan a otras obras de la autora, serán citadas de forma estándar.
} 
culpa al verdugo. Las complicidades trabadas entre todos no son fáciles de discernir" (Castellanos, 2004: 184). Un poco más tarde en 1966 escribe en Juicios sumarios: "En el combate no hay vencedor. El más débil cae en la fascinación, se convierte en una cosa pasiva y opaca" (Castellanos, 1998: 641).

Para comprender cómo puede ser posible que el individuo sometido colabore con su propio proceso de dominación es importante recordar el presupuesto de las dinámicas sociales que William Isaac Thomas (1863-1947), sociólogo de la Escuela de Chicago, elaboró en lo que se conoce como el Teorema de Thomas y que puede considerarse un verdadero axioma social: "Si los individuos definen una situación como real, esa situación es real en sus consecuencias" (Thomas, 2005: 27). Michel Foucault no cita textualmente a Thomas pero en Vigilar y castigar (1998) afirma que "una sujeción real nace mecánicamente de una relación ficticia" (p. 206). Va más allá y precisa las consecuencias de este hecho en las relaciones de poder:

De suerte que no es necesario recurrir a medios de fuerza para obligar al condenado a la buena conducta, el loco a la tranquilidad, el obrero al trabajo, el escolar a la aplicación, el enfermo a la observación de las prescripciones. Bentham se maravillaba de que las construcciones panópticas pudieran ser tan ligeras: nada de rejas, ni de cadenas, ni de cerraduras formidables; basta con que las separaciones sean definidas y las aberturas estén bien dispuestas. La pesada mole de las viejas "casas de seguridad", con su arquitectura de fortaleza, puede ser sustituida por la geometría simple y económica de una "casa de convicción". La eficacia del poder, su fuerza coactiva, han pasado, en cierto modo, al otro lado al lado de su superficie de aplicación. El que está sometido a un campo de visibilidad, y que lo sabe, reproduce por su cuenta las coacciones del poder; las hace jugar espontáneamente sobre sí mismo; inscribe en sí mismo la relación de poder en la cual juega simultáneamente los dos papeles; se convierte en el principio de su propio sometimiento. Por ello, el poder externo puede aligerar su peso físico; tiende a lo incorpóreo; y cuanto más se acerca a este límite, más constantes, profundos, adquiridos de una vez para siempre e incesantemente prolongados serán sus efectos: perpetua victoria que evita todo enfrentamiento físico y que siempre se juega de antemano (Foucault, 1998: 206).

El poder entonces sería como un contrato entre dominados y dominadores escrito con tinta invisible a través del cual los sujetos aceptan y validan presupuestos sociales falsos y sin sustento que fortalecen al poderoso y encadenan y esclavizan al oprimido quien contribuye cerrando con su propia mano las cerraduras.

Pueden distinguirse tres formas simbólicas de dinámicas de poder en la poesía de Rosario Castellanos: la cárcel y el encierro; el éxodo; y la invisibilización. La gran metáfora del poder en su poesía es la cárcel: "como una cárcel es" (46); "inevitable cárcel de ceniza" (20); "Monólogo en la celda" (183). En el mismo sentido, la metáfora del encierro: "Días y días enteros de encierro" (157). La cárcel y el encierro encarnarían la analogía del sujeto vigilado y castigado de Michel Foucault:

Este espacio cerrado, recortado, vigilado, en todos sus puntos, en el que los individuos están insertos en un lugar fijo, en el que los menores movimientos se hallan controlados, en el que todos los acontecimientos están registrados, en el que un trabajo ininterrumpido de escritura une el centro y 
la periferia, en el que el poder se ejerce por entero, de acuerdo con una

figura jerárquica continua [...] (Foucault, 1998: 201).

La segunda forma bajo la cual el poder se representa en la poesía de Castellanos es la exclusión y el rechazo. El poder destierra: "Porque yo soy el éxodo" (48). Como señala Foucault, el poder es también "una práctica del rechazo, del exilio-clausura" (Foucault, 1998: 202). Este autor afirma que en el esquema de la exclusión del poder, el sometido es tratado como "apestado" (Foucault, 1998: 202). Rosario Castellanos escribe:

Y fui como el que muere en la epidemia,

sin identificar, y es arrojado

a la fosa común (292).

Otra forma de representación del ejercicio del poder en la poesía de la autora mexicana consiste en invisibilizar al otro. Anular, borrar, quitarle realidad a otro sujeto por medio de la negación de la percepción es una de las estrategias más totales y devastadoras del poder en Castellanos:

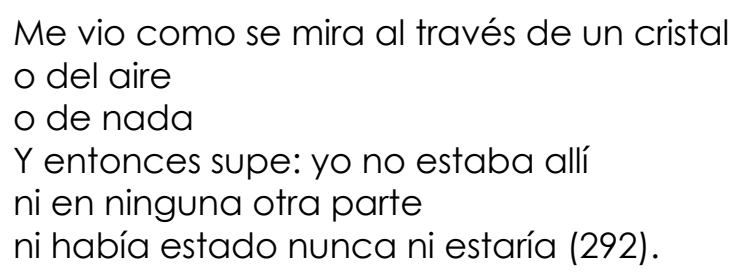

Es importante subrayar que sea cual sea la estrategia de poder representada en su obra: la cárcel, el destierro o la invisibilización; todas pasan por el cuerpo. Se trata aquí claramente de lo que Michel Foucault llama bio-poder, término acuñado en el primer volumen de Historia de la sexualidad. La voluntad de saber en 1976:

El establecimiento, durante la edad clásica, de esa gran tecnología de doble faz -anatómica y biológica, individualizante y especificante, vuelta hacia las relaciones del cuerpo y atenta a los procesos de la vidacaracteriza un poder cuya más alta función no es ya matar sino invadir la vida enteramente (Foucault, 1986: 169).

El poder no es solo ni especialmente un asunto de ideas o de mente, se ejerce sutil y violentamente en el cuerpo mismo, a través del cuerpo. Así Castellanos escribe que lo que sabe del poder lo sabe con su propia carne:

Así, como a la flor del cardo, nos destruye.

Lo supe con mi carne (98).

Los sometidos, los sojuzgados son gente que no existe, que no tiene cuerpo:

[...] que gente como yo no existe.

Porque su cuerpo no proyecta sombra,

porque no arroja peso en la balanza (302).

El poder logra que el sometido sienta que su cuerpo es irreal, fantasmal:

Escribo porque yo, un día, adolescente,

me incliné ante un espejo y no había nadie.

¿Se da cuenta? El vacío [...] (302). 
Castellanos representó entonces simbólicamente en su poesía la realidad y los efectos de lo que Foucault llamó en su conferencia en 1976 en la Facultad de Filosofía de la Universidad de Brasil: Las redes - o mallas - del poder:

\begin{abstract}
Lo que es interesante es, en efecto, saber, cómo en un grupo, en una clase, en una sociedad operan mallas de poder, es decir, cuál es la localización exacta de cada uno en la red del poder, cómo él lo ejerce de nuevo, cómo lo conserva, cómo él impacta en los demás, etcétera (Foucault, 1976).
\end{abstract}

En la poesía de Castellanos el problema del poder y sus efectos en las interacciones sociales, así como en la conformación de la identidad de los sujetos implicados se vincula con el problema del mal en una dimensión metafísica. No es raro que se plantee la realidad que examina en estos términos, es narradora y poeta, pero es también una filósofa. En el siguiente apartado se trata esta relación.

\title{
2. El problema del poder y el mal metafísico en la poesía de Rosario Castellanos
}

Desde los años sesenta Rosario Castellanos tiene presente la perspectiva de que las carencias y miserias propias de la condición humana, y también las que son consecuencia de relaciones sociales parciales, desiguales y abusivas constituyen una dimensión del mal metafísico. En Juicios sumarios escribe: "ciertas experiencias que el hombre padece (especialmente la muerte, pero también todas las otras formas del mal, del sufrimiento y de la injusticia)" (Castellanos, 1998: 659). Los efectos que generan las redes perversas del poder son interpretados en su poesía como una manifestación del mal metafísico.

El símbolo de la cárcel como una de las formas de representación del poder en Castellanos se desplaza en su poesía hacia una expresión del mal metafísico en tanto que el cautiverio es un símbolo del mal "ya no una 'cosa' exterior, sino una fuerza real que somete [...] es un esquema de existencia" (Ricœur, 2003: 265). El ser dominado, preso, cae en un pozo sin fondo, poco a poco pierde sustento, corporeidad, identidad. Según Abbagnano (2008) la concepción metafísica del mal consiste en considerarlo "como el no- ser frente al ser, que es el bien" (678), así leemos en Castellanos el mal como ausencia, como vacío, como no ser:

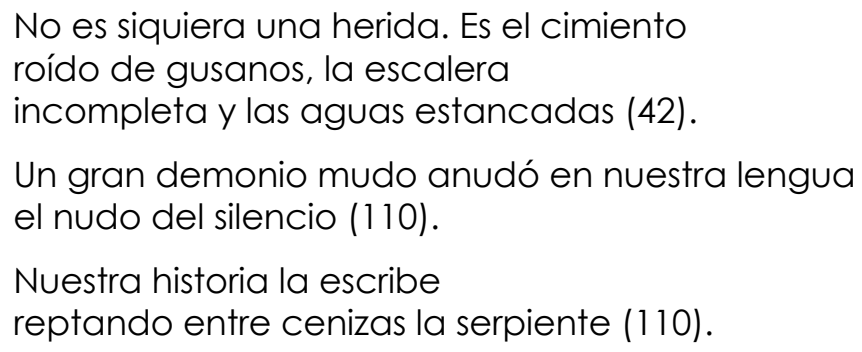

El mal se expresa también como una dualidad del ser o como un contraste interno del ser mismo. En esta segunda concepción metafísica del mal "se trata de una concepción por la cual el dominio del ser está dividido en dos campos opuestos, dominados por dos principios antagónicos" (Abbagnano, 2008: 679). En Rosario Castellanos puede verse cómo se funde en la imagen del nudo la representación de la mujer abrumada por entorno de poder y al mismo tiempo presa de enormes contradicciones internas: 
Este nudo que fui (inextricable

de cólera, traiciones, esperanzas,

vislumbres repentinos, abandonos,

hambres, gritos de miedo y desamparo) (191).

Según el filósofo español Ferrater Mora (2009) "el mal es una apariencia, una ilusión, un velo que impide la visión de bien, identificado con el ser" (p. 2256) y que desencadena un sufrimiento moral o físico. En este sentido, la poesía de Castellanos identifica el poder, el mal y el sufrimiento:

No, yo no quiero hablar de nuestras noches

cuando nos retorcemos como papel al fuego (10).

En este ay me está doliendo el mundo.

Me duele en mí, criatura donde el mal

revienta como pústula (83).

La autora muestra en su poesía una identidad entre los efectos que genera el despliegue del poder injusto e inquisidor en los individuos, el poder que arrasa al sujeto desemboca para Castellanos en una experiencia del mal. El mal se inscribe en la realidad social e histórica de la problemática del poder. Los efectos de las relaciones injustas de poder arrojan al individuo a la soledad, que es equiparada con el mal a través del símbolo de la mancha:

Nací en la hora misma en que nació el pecado

y como él, fui llamada soledad.

Gemelo es nuestro signo y no hay aguas lustrales

capaces de borrar lo que marcaron

los hierros encendidos en mi frente (20).

Castellanos observa, desde una perspectiva filosófica, un paralelo entre la realidad del poder y lo que Ricœur llama la realidad del mal. La escritora expresa simbólicamente el mal a través de la imagen de un Dios inclemente. En esta representación bien puede haber influido la cosmología cristiana de los orígenes de la escritora, de cualquier modo, la imagen de Dios en su obra es un Dios mudo, ausente:

¡Qué implacable fue Dios [...] (9).

¿Escondes el misterio de un dios o eres su cólera que se desencadena al infinito? (24)

¿Cómo fue Dios quedándose sordo y mudo y ausente,

irremediablemente atrás como la aurora? (26)

Y Dios no ha de mirar (52).

Paul Ricœur explicó ampliamente que:

no hay lenguaje directo, no simbólico, del mal padecido, sufrido o cometido [...] Ya se trate de una imagen de la mancha en la confesión mágica del mal como impureza; o de las imágenes de la desviación, el camino torcido, la transgresión, el error, en la concepción más ética del pecado; o de las imágenes del peso y la carga, en la experiencia más interiorizada de la culpabilidad (Ricœur, 2003: 263).

Para este autor la dinámica de los símbolos primarios del mal queda así constituida por las tres constelaciones de la impureza, el pecado y la culpabilidad. 
"En consecuencia, no nos sorprenderá el hecho de que la impureza, el más arcaico de los símbolos [...] desde un principio, la impureza es más que una mancha; situada con relación a lo sagrado, apunta a una afección de la persona en su totalidad" (Ricœur, 2003: 265).

En la poesía de Rosario Castellanos una sociedad regida por relaciones de poder, por la confrontación desigual entre fuertes y débiles, por amos y obedientes, configura un mundo truncado y carente, un mundo errado sellado por el mal:

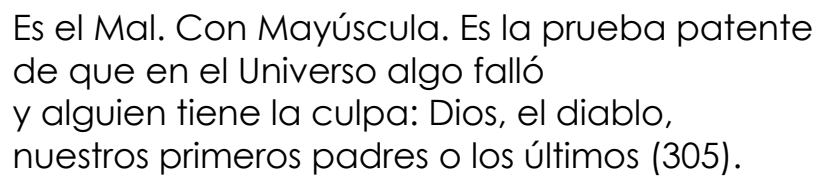

La escritora mexicana, sin embargo, no se detiene en estas conclusiones, aunque el trayecto es parcial y vertiginoso, se aproxima a un proceso de trascendencia de sus circunstancias y emprende un proceso de liberación. Como señaló Carlos Monsiváis:

Las transformaciones del proceso social precipitan la liberación de las fuerzas narrativas y poéticas de Rosario [...] se harta de los papeles y de las imposiciones culturales, y opta por la libertad a partir de la conducta y los gestos espontáneos (Monsiváis, 2008: 301).

En una conferencia impartida en la Universidad de Lausana en 1985, Ricœur explicó que "el problema del mal no es solamente de índole especulativa [sino que] exige una convergencia del pensamiento y la acción (en el sentido moral y político)" señalando además que "la respuesta -no la solución- de la acción es: ¿̇qué hacer contra el malẹ" (Ricœur, 2007: 60.).

Si en su poesía se advierte una equivalencia entre un mundo regido por las redes siniestras del poder y la experiencia del mal metafísico, ambas dimensiones pueden ser trascendidas. En su proyecto poético expresa este proceso simbólicamente a través de rituales de liberación que toman la forma de lavar o purificar:

Los ritos de purificación apuntan, mediante gestos sustituibles (enterrar, escupir, arrojar lejos, etcétera) a una integridad que no puede decirse en otro lenguaje que no sea simbólico. Por esa razón [...] la concepción mágica de la impureza nos ha transmitido la simbólica de lo puro y de lo impuro, con toda su riqueza de armónicos (Ricœur, 2003: 265).

\section{Rituales de liberación: hacia la autoafirmación}

Un ritual "es un acto individual o colectivo que siempre, aun en el caso de que sea lo suficientemente flexible para conceder márgenes a la improvisación, se mantiene fiel a ciertas reglas que son, precisamente, las que constituyen lo que hay en el de ritual" (Cazeneuve, 1971: 16). El rito es por tanto, gratuito, repetitivo, fundador y purificador (Poupard, 1997: 1527).

Los rituales constituyen según Cazeneuve (1971: 15) una necesidad y aunque no tienen utilidad poseen efectividad, representan por ello acciones que, de algún modo, provocan consecuencias reales.

En la poesía de Rosario Castellanos pueden advertirse una serie de rituales liberadores y purificadores que aproximan al sujeto lírico hacia la autoafirmación. 
Por supuesto dichos rituales no constituyen procesos de liberación y autoafirmación en sí mismos, pero son la expresión simbólica en su poesía de esos procesos.

No se abordarán aquí símbolos primarios purificadores y liberadores sino estrictamente rituales, es decir, actos repetidos, estructurados y fundantes no utilitarios y con un sentido de transformación del ser. Es importante notar que todos los fragmentos poéticos citados sugieren una acción estructurada, reiterada y que están en tiempo presente lo que confirma su esencia ritual que tiene la cualidad de transmutar el tiempo cronológico en un tiempo mítico fuera del tiempo, en un Kairos, en términos de Gilbert Durand (1989), un lapso de tiempo crítico, decisivo e indeterminado en el que sucede algo sustancial.

Dice Ralph Metzner en Las grandes metáforas de la tradición sagrada que "el único y más importante requisito previo para escapar de una prisión es el despertar" (Metzner, 2005: 99) y que si se desea desatar un nudo, primero debe saberse cómo fue atado. Este es el proceso que puede leerse en la poesía de Castellanos y que pasa por nueve formas rituales.

El primer ritual que puede verse es el de las lágrimas, lo que Monsiváis llamó en Rosario Castellanos: "la utilidad del llanto" (Monsiváis, 2008: 285). Así puede leerse a lo largo de su obra poética:

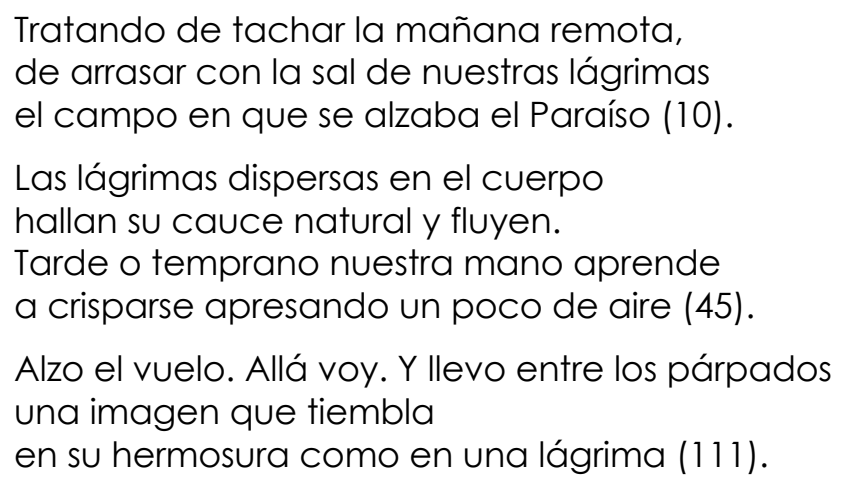

Las redes perversas del poder encarnan un mal metafísico en Castellanos y "todo mal es simbólicamente mancha: la mancha es el 'esquema' primero del mal" (Ricœur, 2004: 208). Las lágrimas constituyen un ritual que lava el mal. Este valor ritual de las lágrimas se debe

en parte al hecho de que las lágrimas están previamente inmunizadas por el simbolismo de la ablución. Las lágrimas son como ríos de agua corriente. Purifican, lavan, bañan los ojos, ¿̇cómo podrían contaminar? Pero más significativamente las lágrimas no se relacionan con las funciones corporales de la digestión o de la procreación. Por lo tanto, es más estrecha su esfera de acción para simbolizar las relaciones y los procesos sociales (Douglas, 1973: 169).

Hay en la poesía de la autora mexicana otras formas rituales de purificación por agua:

Mujeres de la espuma

y el ademán que limpia,

halladme un río hermoso

para lavar mis días (71). 
Según Durand sea por lágrima o por agua, los rituales por lavado representan una forma de bautismo purificador:

todo bautismo o iluminación consiste para el hombre en 'desligar', 'desgarrar' los lazos y los velos de irrealidad, y como lo escribe Eliade, la situación temporal y la miseria del hombre 'se expresan con palabras clave que contienen la idea de ligadura, de encadenamiento, de atadura' (Durand, 2004: 173).

Estos rituales líquidos asumen en la poesía de Castellanos un valor simbólico de liberación por la limpidez de aguas lustrales: "El agua lustral es el agua que hace vivir más allá del pecado, la carne y la condición mortal [...] 'el agua viva', 'el agua celestial', se encuentra tanto en los Upanisads, como en la Biblia o en las tradiciones celtas y romanas" y continúa señalando que "la misma palabra puro, raíz de todas las purificaciones, significa 'fuego' en sánscrito" (Durand, 2004: 178, 179).

El segundo ritual en la poesía de Rosario Castellanos es el fuego purificador que se vincula a la verdad que arde:

Carbones encendidos han limpiado mi boca (52).

El centro de la llama

mi centro.

Aquí arder, aquí hablar

lo verdadero (95).

El tercer ritual es el de la mujer que se enraiza en lo vegetal, la mujer que se ancla a la tierra, el de "la mujer de atributos vegetales" (59) que baila, cosecha, habla con la tierra:

(Cuajada de cosechas bailo sobre las eras

mientras el tiempo llora por sus guadañas rotas) (33).

Ceiba que disemina

mi raza entre los vientos,

sombra en la que se amaron

mis abuelos (63).

Me quedaré a tu lado,

amiga,

hablando con la tierra

todo el día (64).

Con un gesto de tierra abro los brazos (88).

El cuarto ritual es el del arquetipo de la madre como fertilidad y fecundidad simbólica, la mujer que cumple más que biológicamente, míticamente su ritual de ser madre, generadora, dadora de vida:
A ratos, fugitiva del sollozo
que paulatinamente me estrangula,
vuelvo hacia las praderas fértiles y lo invoco
con las voces más tiernas y el nombre más secreto.
¡Hijo mío [...] (38).
Quedé abierta, ofrecida
a las visitaciones, al viento, a la presencia (300). 
El quinto ritual es el despliegue del aire y los pájaros. "El aire resume todas las calificaciones catárticas de los epítetos elementales [...] translucidez, luz, receptividad tanto al calor como al frío" (Durand, 2004: 182), incluye el acto mismo de la respiración liberadora y purificadora del cuerpo. "Esta concepción alcanza una creencia universal que ubica en el aire respiratorio la parte privilegiada y purificada de la persona: el alma" (Durand, 2004: 183). Rosario Castellanos escribe:

Yo no tendré vergüenza de estas manos vacías ni de esta celda hermética que se llama Rosario. En los labios del viento he de llamarme árbol de muchos pájaros (59).

Huye la tierra, vuela como un pájaro.

Su fuga traza estelas redondas en el aire,

frescas huellas de aromas y señales de trinos.

Todo viaja en el viento, arrebatado.

¡Ay, quién fuera un pañuelo,

sólo un pañuelo blanco! (57)

Sobre mi rostro cruza la procesión de pájaros (89).

¡Ah, despertar, vivir,

amar, amar el viento

como un amor de pájaro! (97)

"La mayoría de las religiones también reconocen ese isomorfismo de lo celeste y lo luminoso" (Durand, 2004: 151). El ritual del aire se vincula al simbolismo purificador de lo celeste, dorado y precioso:

$$
\begin{aligned}
& \text { [...] va esparciendo en el aire } \\
& \text { el polvo de oro de un jardín lejano (95). } \\
& \text { Hechizada, contemplo el milagro de estar } \\
& \text { como en el centro puro de un diamante (97). }
\end{aligned}
$$

El aire que se respira en la poesía de Castellanos adquiere entonces un matiz vaporoso y brillante: "Bachelard muestra a las claras que ese cielo azul, privado del tornasol de los colores, es una fenomenalidad sin fenómeno, suerte de nirvana visual que los poetas asimilan unas veces con el éter, el aire 'purísimo' (Durand, 2004: 152153).

El sexto ritual es la purificación y trascendencia que pasa por el dolor:

Convaleciente de tu amor y débil

como el que ha aposentado largamente en sí mismo

agonías y fiebres,

salgo, purificada y tambaleante (41).

Alguien, yo, arrodillada: rasgué mis vestiduras

y colmé de cenizas mi cabeza (48).

El séptimo es el de la tejedora encarnado en el arcaico símbolo de la trenza, si bien las tareas de hilado y tejido son tratados en las mitologías como tradición femenina frecuentemente asociados a espacios oscuros o no visibles. Ciertamente como estudia Olaya Fernández (2012) las Moiras, Atenea y Ariadna, y las divinidades griegas simbólicamente vinculadas a tareas relacionadas con el hilado y el tejido pueden ser replanteadas en términos de empoderamiento a la luz de relecturas de 
estas tradiciones y mitologías. En la poesía de Castellanos, en el ámbito doloroso del poder y el mal, los días pueden destejerse:

Se destejen los días,

las noches se consumen antes de darnos cuenta;

así nos acabamos (116).

Pero bajo la acción de la práctica ritual, todo se teje, se entreteje, se llena de vida y armonía, sea en la trenza que ata o en el cabello destrenzado, libre; la simbólica de la pureza y la libertad expresada en el cabello suelto. La vida misma es la gran e indiscutible tejedora en la poesía de la escritora mexicana:

deja el muro que te aprisiona y anda

con la mujer de trenzas esparcidas (65).

A cantar en los patios,

con las otras mujeres

destrenzadas,

himnos de gratitud

y coros de alabanza (90).

Considera alma mía, esta textura

áspera al tacto, a la que llaman vida.

Repara en tanto hilos tan sabiamente unidos [...]

Piensa en la tejedora; en su paciencia

para recomenzar

una tarea siempre inacabada (114).

Con respecto al ritual del tejido, Neumann subraya que:

Todo lo esencial de la cultura arcaica humana es creado por lo femenino y su espíritu de invención. Los trabajos elementales como la conservación del fuego, la preparación de los alimentos y de las bebidas embriagantes, la confección de ropas, el hilado y el arte de tejer, la alfarería, etc. pertenecen al ámbito primigenio de lo femenino. Originariamente no son realizaciones <<técnicas>>, en el sentido de la conciencia patriarcal, sino rituales de satisfacción simbólica [...] También aquí, con una sorprendente coherencia, la actividad de lo femenino vuelve a ser iluminada por la de la luna, pues la luna aparece como hilandera y tejedora, como señor de los cocidos, de los pucheros y de los trenzados, como inventor de los vestidos y de los adornos para el cuerpo [...] (Neumann, 2004: 65).

El octavo ritual es el de mayor belleza en la poética de Rosario Castellanos, es además el que evoca los orígenes de la escritora, su temprana infancia en Chiapas. Es el ritual del ámbar y se ubica en el poema "Talismán". Como ha explicado Juan Eduardo Cirlot los talismanes "existen desde la más remota antigüedad, apareciendo en Mesopotamia y Egipto ya en el III milenio" (Cirlot, 1992: 427). En el poema "Talismán" se funden además todas las purificaciones anteriores: tejer, enraizarse en la tierra, lavar, escribir, relatar:

Aquí estoy. Tejedora, lavandera,

desgranadora de maíz y, a veces, en la noche,

cuando el sueño no acude,

relatora de historias (214).

En las tres últimas líneas escribe: 
Y ha puesto entre mis manos este pedazo de ámbar para que me recuerden

-después, cuando yo muera- aquellos que me amaron (215).

El ámbar es una resina fosilizada de origen vegetal, su nombre viene del árabe y significa "lo que flota en el mar", sus connotaciones pasan por lo vegetal, por la corteza y savia de los árboles, el paso inmemorial del tiempo que lo fosiliza, su valor como gema preciosa, la transparencia y luz de su color iridiscente, su belleza y al mismo tiempo la resistencia y solidez de su naturaleza. El ámbar además tiene un importante valor en la historia de México ya que tuvo

finalidades ornamentales y ceremoniales. La importancia de los minerales ornamentales para las culturas mesoamericanas se refleja en la riqueza de la lengua náhuatl en términos referentes a minerales y rocas, así como en la abundancia de piezas elaboradas con estos materiales en la gran mayoría de sitios arqueológicos del país. Entre los minerales que logran reunir las cualidades necesarias para ser considerados gemas, el ópalo, el ámbar, la fluorapatita, el topacio y la danburita son cinco de las más emblemáticas y apreciadas en México (Cruz, Canet y Peña, 2007: 9.).

Para apreciar el valor ritual del ámbar en la poesía de Castellanos es esencial recordar que la escritora pasa su temprana infancia en Chiapas en donde esta gema es altamente significativa:

En México, todos los yacimientos económicos de ámbar se encuentran en el estado de Chiapas [...]. El ámbar de Chiapas tuvo un significado y una importancia especiales para las culturas mesoamericanas, que lo usaron para elaborar ornamentos y para realizar ofrendas funerarias. Por este motivo, fue objeto de un intenso comercio por parte de los pobladores autóctonos de Chiapas, principalmente chontales, tzotziles y zoques, y su destino fue, principalmente, la elite azteca (Ytuarte-Núñez, 2001 en Cruz, Canet y Peña, 2007: 13.).

Como señala Lowe:

Sin duda la descripción más completa que ha llegado hasta nosotros acerca del ámbar prehispánico es la registrada por fray Bernardino de Sahagún hacia mediados del siglo XVI en el Códice Florentino, su magna obra bilingüe: 'El ámbar desta tierra se llama apozonalli. Dícese desta manera porque el ámbar desta tierra o estas ansíllamadas son semejantes a las campanillas o enpollas del agua cuando las da el Sol en saliendo, que parece que son amarillas claras, como oro. Estas piedras hállanse en mineros en las montañas. Hay tres maneras destas piedras: la de una manera dellas se llama ámbar amarillo. Estas parecen que tienen dentro de sí una centella de fuego. Son muy hermosas' (Lowe, 2005).

El noveno ritual es el más importante, el más aglutinante, el que libera y salva, el ritual de la escritura. Recuérdese además que el texto escrito es también un tejido ya que etimológicamente texto viene del latín trama, tejido. Rosario Castellanos escribe: "el rumor del espíritu en libertad: la hoja" (107) y entonces el ritual se cumple:

Mientras escribo escucho (57).

La humedad germinal se escribe, sin embargo,

en la celeste página de las constelaciones (107). 
He aquí la obra, el libro (107).

No dudéis de la mano con que escribo (223).

[..] y esta

ampolla que entorpece la mano con que escribo (291) .

Escribo. Este poema. Y otros. Y otros (298).

\section{Conclusiones}

Vemos entonces cómo estas técnicas simbólicas de purificación por la espada, el fuego, el agua $\mathrm{o}$ el aire subsumen obligatoriamente una metafísica de lo puro [...] no son más que soportes de una especie de quintaesencia de la pureza que se manifiesta en ellos por una de sus características: cortante de la hoja, limpidez del agua, luz del fuego, inmaterialidad, levedad y casi ubicuidad del aire (Durand, 2004: 184).

Estos nueve rituales purificadores y liberadores le permiten a la autora mexicana confirmar su identidad en su obra poética y trascender el dolor y el sometimiento, le permiten aproximarse a plantear que es factible romper las cadenas invisibles con que todos los sujetos están atados en la maquinaria del poder, se afirma: "Es como renacer en otros ámbitos/limpios, transfigurados y perfectos" (38).

En su vida y en su obra si algo nunca hizo Rosario Castellanos fue ceder a las imposiciones del poder en sus variadas formas y dimensiones, nunca renunció a su esencia e identidad, a su libertad; buscó siempre por todos los caminos posibles e imposibles, en su vida cotidiana y en su proyecto poético: "Otro modo de ser humano y libre/Otro modo de ser" (329).

\section{Bibliografía}

ABBAGNANO, N. (2008): Diccionario de filosofía. México: FCE.

CASTELLANOS, R. (2012): Poesía no eres tú. México: FCE.

- (2004): Mujer de palabras. Artículos rescatados de Rosario Castellanos. Vol. I. A. Reyes (ed.). México: Conaculta.

- (1998): Obras II. Poesía, teatro y ensayo. México: FCE.

CAZENEUVE, J. (1971): Sociología del rito. Buenos Aires: Amorrortu.

CIRLOT, J. E. (1992): Diccionario de los símbolos. Barcelona: Labor.

CRUZ-OCAMPO, J. \& C. CANET \& D. PEÑA-GARCÍA (2007): Las gemas de México. Boletín de la sociedad sociológica mexicana, LIX, 1, pp. 9-18. Disponible en: http://www.ojs-igl.unam.mx/index.php/bsgm/article/viewFile/262/157 [consultado el 30 de marzo de 2019].

DOUGLAS, M. (1973): Pureza y peligro. Un análisis de los conceptos de contaminación y tabú. Madrid: Siglo XXI Editores.

DURAND, G. (2004): Las estructuras antropológicas del imaginario. México: FCE. 
- (1989): La creación literaria. Los fundamentos de la creación. A. Verjat (ed.) El retorno de Hermes. Barcelona: Anthropos, pp. 20-49.

FERNÁNDEZ, O. (2012): El hilo de la vida. Diosas tejedoras en la mitología griega. Feminismo/s, 20, pp. 107-125. Disponible en: https://www.unirioja.es/genero/archivos/pdf/diosas_tejedoras.pdf [consultado el 30 de marzo de 2019].

FERRATER MORA, J. (2009): Diccionario de filosofía. Barcelona: Ariel.

FOUCAULT, M. (1998): Vigilar y castigar. México: Siglo XXI.

- (1986): Historia de la sexualidad, la voluntad de saber. México: Siglo XXI.

- (1976): Las redes del poder. Conferencia. Disponible en: http://diporets.org/articulos/Las\%20redes\%20del\%20poder.pdf [consultado el 30 de marzo de 2019].

LOWE, L. (2005): El ámbar de Chiapas una gema con historia. Arqueología Mexicana, 74. Disponible en: https://arqueologiamexicana.mx/mexicoantiguo/el-ambar-de-chiapas-una-gema-con-historia [consultado el 30 de marzo de 2019].

METZNER, R. (2005): Las grandes metáforas de la tradición sagrada. Barcelona: Kairós

MONSIVÁIS, C. (2008): Escribir, por ejemplo (de los inventores de la tradición). México: FCE-SEP.

NEUMANN, E. (2004): La conciencia matriarcal. En Arquetipos y símbolos colectivos. Círculo Eranos I. Barcelona: Anthropos, pp. 45-96.

PAZ, O. (2003): Obra poética Il. México: FCE.

POUPARD, P. (1997): Diccionario de las religiones. Barcelona: Herder.

RICOEUR, P. (2007): El mal. Un desafío a la filosofía y a la teología. Madrid: Amorrortu.

- (2004): Finitud y culpabilidad. Madrid: Trotta.

- (2003): El conflicto de las interpretaciones. Ensayos de hermenéutica. Buenos Aires: FCE.

THOMAS, W. (2005): La definición de la situación. Cuadernos de Información y Comunicación, 10, pp. 27-32. Disponible en: https://core.ac.uk/download/pdf/38810897.pdf [consultado el 29 de marzo de 2019].

YTUARTE-NÚÑEZ, C. (2001): Rutas comerciales del ámbar mexicano: Chiapas (comunicación, cultura y política). Tesis de Maestría en Ciencias Antropológicas (inédita). México: Universidad Autónoma Metropolitana. 